\title{
Trials and Triumphs of the Nigerian Media in the Quest for Nation-Building
}

\author{
Thomas AnomoapheAlemoh ${ }^{1}$, Comfort OjomaUkwela ${ }^{1}$ \\ ${ }^{1}$ Dept.of Theatre \& Media Arts, Federal University, Lafia, Nasarawa State, Nigeria \\ Correspondence: Thomas Anomoaphe Alemoh, Dept. of Theatre \& Media Arts, Federal University, Lafia, Nasarawa \\ State, Nigeria.
}

Received: March 1, 2019

Accepted: July 18, 2019

Online Published: August 12, 2019

doi:10.11114/smc.v7i2.4429

URL: https://doi.org/10.11114/smc.v7i2.4429

\begin{abstract}
:
There is no doubt that journalism has gained a foothold in Nigeria as a profession. From the colonial times to the present day, the Nigerian media, as an institution, has proved relevant in the gradual evolution into nationhood of the diverse entities that make up the nation. But one thing is glaring and that is: in spite of the enormous input the Nigerian press has made through an avalanche of sacrifices to the development of the nation, not much scholarly attention is accorded such feats.Emphasis tends to be more on the isolated cases of dysfunctional role the media has played as an institution in the Nigerian society. This paper seeks to redirect intellectual focus to an objective evaluation of the contributions the Nigerian media has made to the development of the country even though, as a caveat, the study does not intend to serve as an alibi for the shortcomings of the press in Nigeria.
\end{abstract}

Keywords: guerrilla journalism, letter bomb, investigative journalism, sensationalism, partisanship

\section{Introduction}

Shortly after the gruesome murder of Dele Giwa, a frontline print journalist and then Chief Executive of Newswatch Magazine on 19 October, 1986 in his home in Lagos, Nigeria, there were conflicting views making the rounds on what might had motivated the masterminds of the dastardly act (using a letter bomb, an unprecedented elimination mechanism in the country) to snuff out the life of that robust and promising icon of investigative journalism in Nigeria. One of such unconfirmed insinuations was that the late Giwa had accepted an offer of a bribe to kill the story on drug trafficking he was purportedly investigating, and which had something to do with those in the corridors of power as at then, but still went ahead with the intention of publishing it.

Another version had it that Dele Giwa was obviously expecting 'something', in this case a 'brown envelope', a euphemism for bribe in Nigerian journalism practice, from the man in the centre of the story who was hell bent on nipping the report in the bud, and so, when the 'expected envelope' finally arrived, it turned out to be a harbinger of death. The question, in response to these glaringly spurious claims, is: if Dele Giwa was actually anticipating a handsome monetary reward from the powers that be as presumed, would he attempt opening the 'expected gift' in the presence of Kayode Soyinka, the then London Bureau Chief of Newswatch Magazine, who was a fellow journalist in that case? But that was what Giwa did in the very presence of the young man in question who by dint of fate was made an unfortunate witness of a macabre episode reminiscent of the savagery and bestiality of the vampire emperors of the dark ages of human history. Going by legal principles, Kayode circumstantially became a prime suspect in the case, although he had been vindicated ever since.

What led to the above revisit to the gallery of media history in Nigeria is the need for a deep feeling of sympathy (or is it empathy?) that the Nigeria public should have for journalists who have demonstrated unalloyed commitment to the pursuit of quality journalism practice geared towards nation building. Adaja (2016, p.70) rightly says "It is noteworthy to commend the role played by the Nigerian media in the socio-cultural, economic and political development of the country from inception in 1859 to the present democratic dispensation". Adaja further cites Williams (2014) that "the narrative of the press is also the narrative of the nation" adding that "Hardly can the media be divorced from any achievements the Nigerian nation has recorded from pre-independence to this democratic dispensation". A Newswatch Assistant Editor, Emmanuel Uffot (2009) while writing on the significance of the Nigeria Media Merit Award (NMMA), quotes the Trustees of the NMMA as saying: “...the NMMA scheme was established in 1990 to recognize excellence 
among media practitioners and organizations because of the realization that the media, as the fourth estate of the realm, has been the most consistent vanguard and venue for the nation's development all through Nigeria's evolution yet the most unheralded" (emphasis mine).

This article aims at affirming the validity of the above assertion that the Nigerian press has largely been an unsung hero. The issue that arises from this backdrop, therefore, is the question of how the media and journalists in Nigeria are perceived by the Nigerian public and by extension the global audience. This paper focuses on the Nigerian media performance although the analysis may reflect global realities with regard to societal recognition of the perilous job of journalists and their worthy contributions to human development. As a caveat, this article should not, however,be interpreted as a Public Relations piece to polish the image of the Nigerian media neither is it intended to serve as an alibi for its shortcomings. Instead, the paper aims at redirecting attention to the salient point that the Nigerian media institution needs to be objectively assessed in its onerous role as regards national development in the context of the multiple challenges facing the industry and daunting circumstances it has surmounted in order to save the ship of state from a possible torpedo.Against this background, this paper seeks to highlight the various ways in which media reportage of issues in the affairs of this country has helped the nation to weather the storms in her political history. We shall be looking at some episodes in the life of the nation against the backdrop of how the Nigerian media waded into such issues and possibly charted a course for the nation to forge ahead. It will be seen that the Nigerian media, as an institution, has been in the vanguard of national development in the country and has sacrificed much for the growth of the nation.

\section{Theoretical Framework for the Study}

This discourse is anchored on the agenda setting theory of the media, social responsibility media theory and development media theory. From the angle of the Agenda Setting theory, whatever contribution the Nigerian media has made or is making to the development of this nation is achieved through the ability of the media to guide the consciousness of the nation by raising national issues to the surface level of public discourse. Owing to the prominence given to such issues in terms of coverage, they gradually gain attention of the public as well as those in authority (Asemah, 2011, pp.176-177). By so doing, the media are able to influence the public opinion and ultimately the decisions of government.

On the part of the public, the media are able to consciously direct the focus of the former to the issues at stake. In this way, the media do not necessarily think for the society, as it might be logically presumed, but they guide the society on what to think about. Consequently, any issue that the media ignore in any society automatically becomes a non-issue, no matter how significant it could be. In the same vein, the media could make a non-issue appear significant. Evidently as this paper argues, the Nigerian media has been able to guide the conscience of the Nigerian society by opening the Pandora box to expose the shady deals of high profile public figures and moderating public discourse on quite a number of controversial issues bordering on national development. Such vexed issues include the Sharia debate, resource control, restructuring the nation, and sovereign national conference.

This work is also supported by the social responsibility media theory; a part of which stresses the herculean oversight role of the media in holding the government accountable to the governed. This is also in line with the constitutional provision for the role of the press in Nigeria in Section 39 of the 1999 constitution (as amended) which empowers the media to hold the government accountable to the governed. It is important to remark here that little progress can be made in any society where leaders are accountable to no one. Most likely in such a situation, the business of statecraft would be converted to gratifying some self-seeking propensities on the part of those in control of power to the detriment of the people. A clear case study of this institutional anomaly in the political annals of Nigeria was the military era in Nigerian politics. Aina writing in Unilag Communication Review (2003, p.126) quotes Richard Joseph as saying that under such moments of administrative absurdities "offices and resources of the state become no more than the private estates of the occupants of state power at any particular time." Therefore, the need for a watchdog over the conduct of national leaders becomes paramount in a civilized society if the leaders are to be responsible and committed to what has been entrusted into their hands. The media in Nigeria has not only being watching the goings-on in government but has been barking where the rules of the game seem to have been infringed upon by those who exercise the apparatus of power. Incidences of such nature are highlighted in this paper.

This paper further relies on the Development Media theory which heaps on the media the onerous task of aiding the development process in any society through the instrumentality of communication. Here, the media are to support the development efforts of the government and other non-governmental bodies for the overall growth of the nation. Development communication in simple terms means applying communication to development purposes. What this boils down to is that through constructive reportage with focus on developmental needs of the nation in terms of harnessing both human and material resources, the media could accelerate the pace of advancement in the society. This paper 
argues that the Nigerian media has been in the vanguard of propagating ideas, initiating innovations, and assisting in consolidating the policies and programmes of government/non-governmental bodies in the country geared towards moving the nation forward.

\section{The Hazardous Nature of Journalism Practice}

Indeed, journalism, by its nature, is a public service oriented profession that rewards the practitioner far less than what the society benefits from its services especially in the developing countries. The Association for Education in Journalism and Mass Communication Task Force on Curriculum notes in this regard as cited in Oguche \&Tiamiyu (2018, p.171) that "...the purpose of media education is to produce well-rounded graduates who have critical thinking skills as well as practical skills, and who have an understanding of the philosophy of the media and a dedication to the public service role that the media have in our society" (emphasis mine). However, whereas journalism in the western world has grown to be a lucrative profession in which some of its practitioners and stakeholders are counted among the rich of the world, in third world countries, the reverse is the case as journalists are underpaid and ill-treated by influential individuals, organizations and even the government at times. In spite of the hazards, the journalists are still committed to their job.For instance, one would wonder what the journalist would gain at the risk of his life from trailing a drug baron, serial killer or a notorious criminal, to mention just a few, for months without end in order to bring them to book. In live coverage of crisis and war situation, journalists dressed in military fatigue (camouflage) dodge bullets while taking snap shots of news worthy scenes or try to ferret out information from a monstrous looking warlord in the jungle. Such a task is even more perilous for journalists in the third world than their counterparts in the western world who use drones and other technological ancillaries in covering events in a dangerous terrain.

It is so discomforting to observe that whenever a journalist is killed usually in cold blood, the issue is at best reported as a news story without the culprits being brought to book just like in the case of Dele Giwa mentioned in the introduction to this article. The truth of the matter is that journalists who trade their lives for the good cause of the nation are the true heroes that should be celebrated by all because a panacea to extricating every society from the grip of evil-minded gladiators is dogged investigative journalism. Certainly, the demise of Dele Giwa and other journalists in Nigeria and the rest of the world is not in vain and nemesis would continually hang like the proverbial Sword of Damocles on the neck of the perpetrators of those inhuman acts. As if it was a premonition, Dele Giwa had remarked in one of his columns that 'any evil done by man to man must be redressed if not now but certainly later; for the victory of good over evil is but temporary'.

\section{Perception of the Role of the Media in Nigeria}

Quite unfortunate, when it comes to media analysis in Nigeria particularly with regards to their role in national development, not much attention is given to the sacrifices the Nigerian media has made to the development of the nation. Pate (2012, p.60) citing Egwu (2001), Galadima (2005) and Aina (2005) has observed that "Arguably, one institution that has often been accused of negative performance in the management of diversity and conflict issues in the country is the press partly for 'its role in the exacerbation' of ethnic and religious violence" (my emphasis)

In this regard, some see the Nigerian media as emphasizing 'those things that divide us than what unite us as a people'. The media are said to be partisan and divided along tribal and religious lines. While these allegations may not be easily dismissed with the wave of the hand as some have empirical evidence to prove them, it equally lacks objectivity to conclude that the Nigerian media should be held responsible for the current woes of the nation. It is important to $\mathrm{x}$-ray the travails and triumphs of the Nigerian media in scholarly writings rather than over-emphasizing a catalogue of its excesses couched in derogatory terms like partisanship, corruption (Brown Envelop), ethnicity, biased coverage, sensationalism, etc, all brought under the gigantic label of unethical practices.It is worth noting that unhealthy practices are not exclusive to journalism as a profession because other professions are not immune to "sharp practices". Agbanu (2008, p.346) commenting on the non-exclusivity of unethical practices to journalism notes that:

Media reports of physicians prescribing substandard drugs or issue undeserved medical certificate of fitness to patients abound. Lawyers act as counsel to both the plaintiff and the defendant, and oftentimes obstruct judicial process with unwarranted motions and pleas; journalists slant stories to suit personal interest, Public Relations practitioners think only of the interest of their client without considering the adverse effect of the cause they are promoting to the society; Insurance agents swindle clients of large sums of money without giving full details or information about the policy the client is about to take up; bankers often encourage harlotry in the name of scouting for customers or engage in money laundry to make bogus profit or meet recapitalization requirements of the Central Bank. 
We could best imagine what Nigeria as a country would be if the media were not there in the first place to report events in the country or perhaps, the media were dormant by perhaps toeing the line of the ruling authorities. Dominick (2002, p.32) posits that "maybe the best way to appreciate the role that the (sic) mass communication plays in our society would be to imagine what it would be like if, all of a sudden, the whole system never existed". Okpeh (2005, p.164) maintains that "What analysts in a hurry to cast expressions (sic) on journalists seem to forget is that these shortcomings are mere reflections of a basic problem inherent in the society itself." In his view, such problems are "symptomatic of the basic structural deformity of the Nigerian political economy. To effectively tackle this, we must go beyond their manifestations and come to grips with the substance of the ailment itself."

On their part, MacBride, et al (1981, p.22) observe that "sometimes the consequences of disseminating information are not taken into consideration, nor are they viewed as involving any kind of accountability". Okpeh (2005, p.163) again avers that "the practitioners and the profession have also had to content (sic) with poor conditions of service which is reflected in the lack of commitment of some of them arising from job dissatisfaction. It has been observed that Nigeria journalists rank among the world's most underpaid." Okpeh cites Tony Ede, a former Nigeria Television Authority (NTA) member of staff but now Corporate Affairs Manager, Central Bank of Nigeria, CBN, (as at the time of writing) who says, "...it is regrettable that we never sat down to think of the journalist in this country. Do people ever ask whether journalists write or report from the point of vexation or from the angle of frustration?"

\section{Sacrifices of the Nigerian Media towards Nation Building}

Indeed, there is a need for a re-examination of the manner in which the Nigerian media are appraised in the context of their role in national development. The Nigerian media may not have received encomiums from within the country for its role in nation building but it is celebrated as the freest and most vocal in the continent of Africa.This is because the Nigerian media has been able to stake out its neck in the interest of the nation even in the face of daunting challenges and grave dangers. It is not gainsaid that the media has stood out as one institution in Nigeria that has been largely responsible for moving the Nigerian state forward. Adaja (2016, p.61) corroborates this in citing Okenwa (1993) that "the history of the press in Nigeria is closely tied to the history of the country. The fate of Nigerian politics has been charted and determined by the role the early press assigned to itself".

It merits mention that part of this feat was achieved mainly because some of the journalists became 'sacrificial lambs' for the love of their fatherland while some others had to suffer one form of humiliation or the other in the hands of the authorities.The nasty experiences of the likes of Tony Momoh, Minere Amakiri, Bagauda Kalto, Kunle Ajibade, Nosa Igiebor, Onome-Osifo Whiskey, Tunde Thompson, Nduka Irabor, Chris Anyanwu, George Mba, Ben Charles-Obi, Niran Malaolu and a host of other journalists who have been extra-judicially detained sometimes under the worst inhuman conditions or have died in the course of duty just for volunteering to speak the truth cannot easily been forgotten. Quite unfortunate, the murderous manhunt for journalists seems to have bounced back in Nigeria in recent times with the latest victims being Tayo Lukula and Bayo Ohu (The Guardian), Edo Sule Ugbagwu (The Nation), Godwin Agbroko and Abayomi Ogundeji (ThisDay) among others. Similar scenarios have played out again in Ghana, where Ahmed Hussein-Suale, an investigative journalist was murdered near his home and in Istanbul where Jamal Khashoggi, a Saudi journalist was killed within the hallowed premises of the Kingdom of Saudi Arabia Consulate in Istanbul.This is just a tip of the iceberg because as noted by the Committee to Protect Journalists (CPJ), in 2015 alone on the global scene, 39 journalists were murdered worldwide. For more details on this, see http://unpan1.un.org/intradoc/groups/public/documents/un/unpan005902.pdf

Aside of other journalists that lost their lives in Nigeria in the discharge of their duties like Dele Giwa mentioned earlier in this article, Alemoh (2017, pp.162-163) has observed in the report of the Committee to Protect Journalists (CPJ) that since 1992, 10 journalists have been killed in Nigeria (see https://cpj.org/killed/africa/nigeria/). The report gives their records as follows: Enenche Akogwu, Channels TV (January 20, 2012, in Kano); Zakariya Isa, Nigeria Television Authority (October 22, 2011, in Maiduguri); Sunday Gyang Bwede, The Light Bearer (April 24, 2010, in Jos, Plateau State);Nathan S. Dabak, The Light Bearer (April 24, 2010, in Jos, Plateau State); and Bayo Ohu, The Guardian (September 20, 2009, in Lagos).Others are Samson Boyi, The Scope (November 5, 1999, in Adamawa State); Sam Nimfa-Jan, Details (May 27, 1999, in Kafanchan);Fidelis Ikwuebe,Freelancer (April 18, 1999, in Anambra);Okezie Amaruben, Newsservice (September 2, 1998, in Enugu) and Tunde Oladepo,The Guardian (February 26, 1998, in Abeokuta).

\section{The Media in Colonial Nigeria}

We cannot begin an appraisal of the Nigerian media's contribution to nation building without taking a look back into the past of this nation. Wilson Churchill, erstwhile Prime Minister of Britain, is credited with the statement that the further back we look, the further front we see. George Santanaya, another great thinker, notes that those who cannot remember their past are in the danger of repeating it. 
What the above assertions tend to depict is that there is a need to examine the beginning of the Nigerian media and how that humble start has shaped its modus operandi up till the present. Essentially, history shows that the Nigerian media functioned as a catalyst in the struggle for, and eventual attainment of independence for Nigeria. Okpeh (2005, p.163) notes that journalism in Nigeria:

...contributed tremendously in formulating the pristine ideas which gave meaning, substance and relevance to our nationalist struggles which culminated in the grant of political independence in (sic) October 1, 1960. Similarly, after independence, regardless of its obvious weaknesses, the profession, through its instrumentalities, has continued to mobilize the people toward the Herculean task of nation building.

This assertion is equally supported by Adaja (2016, p.59 citing Agbaje, 1992) that the Nigerian media founded and built the consciousness that brought about the establishment of political formations and ideologies that groomed and midwife processes that metamorphosed into the creation and sustenance of the political entity known as Nigeria.

There is no doubt that the press was the rallying point of the nationalists; the press was the mouth piece of the nationalists; the press mobilized, sustained and fuelled the patriotic fervour in the nationalists which culminated in political independence for the country. The statement is true, therefore, that "the Nigerian press was born of anti-colonial protests, baptized in the flood of nationalist struggles and matured in party politics" (Golding, 1983). Earlier, Omu (1978) had observed that even right from inception, the Nigerian media had never been apolitical when the interest of the public was at stake. Affirming this claim, Adaja (2016, p.60) says, "It is instructive to note...that within the first year of establishment of Iwe Irohin which started off as a purely religious newspaper, it got itself involved and engrossed in politics". Adaja gives more evidence in Duyile (2004) who avers that even the Anglo-African newspaper, one of the earliest publications in Nigeria established by Robert Campbell, "...was heavily involved in the politics of Lagos especially in the agitation for the separation of Lagos from the Gold Coast administration". Adaja (2016, p.61) quotes Omu (1978) as saying “...of the more than twelve newspapers which appeared in Lagos between 1880 and 1900 for example only one would not be classified as markedly political in bias".

Omu in Aina (2003, p.124) refers to the nationalists who made use of their newspapers, as "professional and vocational journalists who took a positive role in politics and were active in social life". Omu (1978) further notes that Iwe Irohin, the first newspaper published in Nigeria, waded into the Egba-Lagos conflict by criticizing the colonial government, which earned the paper some hard knocks from the latter. Suffice it to say that what Iwe Irohin inadvertently started at that time has become a defining factor in journalism practice in Nigeria today. James Coleman cited in Aina (2003, p.124) has posited that the early newspapers in Nigeria "have been among the main influences in the awakening of racial and political consciousness". Adaja (2016, p.59) cites Agbaje (2015) who sees "the press (Nigerian media) not as a means to an end but as a vital and indispensable subject in and of itself in the search for better understanding of the Nigerian society". The point we are making here is that right from the onset, the Nigerian media has always been involved in the political development of the nation. Indeed, press and politics in Nigeria has been and still is an area of interest to media scholars in and outside the country.

\section{The Media in Post-Colonial Nigeria}

Just like the Nigerian media fought colonialism to a standstill, in the post-colonial Nigeria, the media once again assumed its watchdog posture of holding the government accountable to the governed. Adaja (2016, p.62) argues that "Although, the Nigerian media space became polarized, that is, between pro-government and the independent press...their surveillance function continued. The struggle for democracy was championed by the Nigerian press".It could be said, however, with ample evidence that the media sometimes erred in carrying out their responsibilities in this regard. But in most cases, the media went out of their way to savage the nation in the face of intimidation and glaring high risks. History again records that a few years after independence, the Nigerian media raised an alarm that the young nation (Nigeria) was drifting apart owing to the manner in which the pioneer indigenous leaders handled the affairs of the country. Unfortunately, the alarm raised aroused the military which felt that it was patriotic on its part to rescue a drowning nation. Commenting on the supposed justification of military intervention in Nigerian politics, Madiebo (1980), an ex-service man in the Nigerian army, submits that "a possible military intervention is perhaps the only check on the excesses of the political class which has neutralized the power of the ballot box". However, we must quickly point out here that this position is no longer fashionable globally and has been vehemently condemned by international organizations like the African Union (AU) and the United Nations (UN). Obviously as at the time, it would be hard for any observer to blame the press nor the military because as history shows, the Nigerian nation was on the verge of collapse in the hands of the First Republic politicians who found themselves entangled in a war of supremacy in the corridors of power (Efiong, 2012, p.18). An aftermath of the unnecessary power tussle was the Western Region Riots of 1964-1965, which paved the way for the 15 January, 1966 military coup, and was closely followed by a counter-coup on 
29 July, 1966. Subsequently, the clearly avoidable carnage called the Nigerian civil war of 1967-1970 had its roots in the crisis situation referred to above.

Abraham Ogbodo, a social analyst and editor of The Guardian (as at the time of writing) commenting on the interventionist role of the press in national crisis of governance observes:

I am, therefore, saying that if the executive, legislature and judiciary are having issues representing democracy the way it should be represented, there is a fourth force in the mix that should massively step in.... This is the media, which has every right under the general rules of democracy and with the status ascribed to it as the fourth arm of government after the executive, legislature and judiciary, to offer help at critical junctures (The Guardian, 24 July, 2016).

It is, however, debatable whether the Nigerian media rendered the needed help to the nation in the right direction in the circumstances under consideration. Worst still, the First Republic politicians sowed the seed for an ethnic based press in the country because as Pate (1997 in Alemoh, 2005, p.70) notes, the NPC dominated Northern Nigeria had the Nigerian Citizen on its side, the West of Action Group (AG) had the NigerianTribune and Daily Service while the East of NCNC had the West African Pilot. Each of these publications including their broadcast counterparts became organs of propaganda in the hands of the regional governments. Suffice it to say that the trend has continued till date in both the private and public media operating in the country whether at the local, state or federal level. It is on record, according to Aina cited earlier, that "at the exit of the colonialists, the nationalist inheritors of state power, realizing the power of the press in influencing public opinion committed government funds to setting up media houses". Uche (1989) in Okon (1997, p.112) observes that "When Nigeria attained independence in 1960, the mass media orientation shifted towards reinforcing tribal and sectional loyalties in preference to the goal of national unity, identity and integration. The press and other media dedicated themselves to the articulation of particular ethnic interests". So, it has been argued according to Aina that "the impact of the nationalists and their newspapers in setting agenda for public discourse possibly led to government intervention in print and electronic media in the 1950s and 1960s". The foregoing analysis provides evidence as averred earlier in this article that some allegations against the Nigerian media playing dysfunctional role in nation building cannot be dismissed with the wave of the hand.

\section{The Media in Military Era}

There is evidence to believe that the Nigerian media has always consciously but diplomatically invited the military to take over the reins of power in Nigeria. Although the first military incursion into the nation's political landscape was at the behest of a beleaguered civilian government which had just lost its Prime Minister and other key government functionaries to a revolt by a group of mutineers in the army (Madiebo, 1980), the influence of the media in preparing the grounds for the incident could still be felt. The media had always prepared the minds of the people for a possible change in government whenever those in power are perceived to have evidently lost focus as far as governance was concerned and were embroiled in inter/intra party squabbles (see Madiebo, 1980;Efiong, 2012). Suffice it to say, though regrettably, that the media had faithfully played this role in the subsequent military putsches in Nigerian history.

Quite unfortunate, when the military struck, it was the media that usually become the first casualty of the former's brutality. By its mechanistic nature, a military regime does not condone opposition no matter how constructive it may be. On the other hand, the media would want to assert its constitutional role of holding the government accountable to the governed (see Cap 2, S.22, Constitution of the Federal Republic of Nigeria). This brings about friction between the two parties and an adversarial relationship between them begins from day one of the life of the military regime. Expectedly, the junta would suspend the constitution which by implication robs the citizens of their fundamental human rights including freedom of expression. The media are consequently caged and this is strengthened by the promulgation of more draconian decrees to gag the press when the latter appears irrepressible.

Sadly, both the Nigerian media and the Nigerian people discovered rather too late that the military held placebo solutions to the socio-political problems of the country. But by this time, the military had entrenched itself in power so formidably that any attempt to make them return to the barracks was greeted with the utmost inhuman reaction. Here again, there was a reversal of role play as the Nigerian media which heralded the military into power became the arrow head in chasing the latter out of office.

The Nigerian media was not only embarrassing the military by exposing corruption in high places in the regimes but was bold enough in the face of sinister challenges to confront the men in uniform and remind them of their constitutional duty of protecting the nation from external aggression and not to rule. Literary speaking, it was a battle of the pen versus the gun. And the pen prevailed! Attesting to this claim, Adaja (2016, p.65) cites Olukotun (2009) who reiterates the comments of a frontline nationalist and statesman, Anthony Enahoro, that, "I send my heartiest appreciation to the heroes of the media without which the battle would have been prolonged, perhaps even lost. I thank 
them all not only for their sacrifices but also for keeping the fires of democracy and free speech burning when it was so easy to have done otherwise". Obviously, the battle in this context was the struggle to exit the military from the corridors of power.

The Nigerian media tellingly sustained deep injuries in this struggle as each military regime had its own way of meting out brutality to the media although some cases are astounding. For instance, the case of the thoroughly beaten and clean-shaven Minere Amakiri, a journalist in detention during the regime of Gen. Yakubu Gowon (1966-1975) cannot easily be forgotten. What of the many media houses that were either shut down or had numerous copies of their publications confiscated in the regime of Gen. Olusegun Obasanjo (1976-1979) and other succeeding regimes. In fact, the Obasanjo regime was reputed for proscription of media organizations. The economic loss accruing from such undeserved repressions amounts to millions of dollars. Unfortunately, little or nothing had ever been done to compensate the Nigerian media for such untold losses and undeserved inhuman treatment even when the law courts give judgement in favour of the media and requesting them to be paid compensatory damages. This is an area in media studies in Nigeria that is nearly completely glossed over by researchers. The Buhari-Idiagbon's administration (1983-1985) would ever be remembered for the infamous Decree No 4 in which two journalists, Tunde Thompson and Iduka Irabor, were sentenced to life imprisonment for no other offence than reporting the activities of government. The duo would always be thankful to God for the quick termination of that regime which had the earmarks of a super-authoritarian government.

Of all the travails of the Nigerian media in the hands of the military, the days of Gens. Ibrahim Babangida (1985-1993) and Sanni Abacha (1993-1998) in almost rapid succession have been labeled as the darkest hours in journalism history in Nigeria. Apart from the use of proscriptive decrees on media organizations, a practice inherited by the juntas in question, state apparatuses were used to hack down media practitioners who dared the despots. These dictators seemed to have realized that indiscriminate arrest, intimidations and incarcerations of journalists alone were not enough measures to deter the journalists from being a thorn in the flesh of the military. Outright elimination of journalists became an adopted policy of the government. This was when the letter bomb incident and Bagauda Kalto's death referred to earlier in this paper were recorded. Abacha scored a point higher by roping in some journalists into a phantom coup in 1995 and out of pressure ended up commuting their death sentences to life imprisonment. Chris Anyanwu, a journalist and erstwhile Senator in Nigeria, is a living testimony of the byzantine proclivities of the Abacha's government.

Surprisingly, in spite of the animalistic tendencies of these regimes towards the Nigerian media, the latter displayed an uncommon resilience in waging war against the former. Leading the offensive were news magazines like Tell and Newswatch complemented by the efforts of some newspapers like the Guardian, Vanguard, Punch, to mention but a few. Remarkably, the Babangida-Abacha years marked the glory of militant press in Nigerian post-independence history. In fact, a new genre of journalism practice emerged from this nasty experience as a legacy -Guerrilla Journalismchampioned by Tell Magazine particularly during Abacha's regime. In guerrilla journalism, a media organization would be publishing from an undisclosed location and in an unpredictable frequency. Adaja (2016, p.62) observes that "The period of military interregnum in Nigeria witnessed a different media operation that was a drastic departure from the conventional method of media operation. Nigerian media and media workers' determination to wrest the reins of governance from the military dictators led to the emergence of 'guerrilla media strategy' or guerrilla journalism". Alemoh (2017, p.161) has advised that "...the present crop of up and coming journalists in Nigeria have much to tap from the reservoir of experience of the veterans who successfully prosecuted the war against the juntas. The lessons of 'guerrilla journalism' need being taught to the contemporary journalists in Nigeria". The Nigerian media was not just reporting the excesses of the regimes tending into full scale, sit-tight dictatorship, but also provided a platform for coordinating the resistance to the military's bid to rule the nation ad infinitum.

Once again, the Nigerian media, like in the colonial times, became a rally point for pro-democracy groups, nationalists and patriots in the struggle for the emancipation of the nation from the pangs of indigenous, exploitative and undeserving leadership. To be candid, one could say that the return to civil rule in 1999 was a gift to the nation purchased with "the blood, sweat and toil" (courtesy of Sir Winston Churchill, ex-Prime Minister of Britain) of the media. An analyst, Bob Anikwe, puts it more succinctly in the May 5, 2010 issue of the Vanguard:

It is largely through the efforts of journalists that the military's 28 years of power stranglehold over our country was broken. The media war waged by radical journalists from the early 1980s provided impetus and support for civil society organizations to come into being and join in this fight. The haste with which Generals Obasanjo (1979), Babangida (1993), and AbdusalamAbubakar (1999) either stepped aside or handed over power to civilians is partly credited to the dogged efforts of the radical media aided by the civil society groups that they encouraged and empowered. 


\section{The Media in Post Military Era}

The return to democracy in Nigeria in 1999 brought in its wake an avalanche of challenges to the nation. Evidently, there were numerous social conflicts generated by those whose interest was threatened in one way or the other by the reformist posture of the emergent administration of Chief Olusegun Obasanjo (1999-2007), a second time head of state of Nigeria but in a civilian garb. Akinlade (n.d) has noted that in spite of the challenges inherent in a democracy, it is still preferred above other systems of government in modern societies. In his view:

The prevalence of democracy as a political system of government among the countries of the world is indisputable. Democracy, over the years in history has come to replace other less popular systems of government like monarchy, theocracy, autocracy, military junta etc. Starting from the American Revolution of 1776, to the French Revolution of 1789, to the Russian Revolution of 1917, democracy swept across the world as the most preferred form of government.

The social upheavals were life-threatening to the corporate existence of the country and there was the need for the government to remain focused in keeping the nation as one entity. A case in point was the Sharia imbroglio in northern Nigeria which, undoubtedly, sparked off reprisals in other parts of the country. Not only that, other events which cropped up in reaction to the Sharia agitation include Resource Control, and Ethnic Self-determination championed by factional leaders among others. Although opinions differ on how objective the Nigerian media was in the coverage of these incidents, the fact remains that the Nigerian media kept faith by following up issues and reporting same to the public thereby informing and educating the audience on what was at stake in line with its agenda setting role. Nevertheless, it is still controversial the extent the media was objective as it is expected of a balanced journalistic practice in presenting both sides to the issue so that the public could be better informed. The pluralistic nature of the Nigerian media provided divergent views on the issues in line with the libertarian philosophy of the "free market place of ideas'. This greatly enriched the populace knowledge of such happenings which paved the way for greater participation in national discourse and a peaceful resolution of most of the crises. At least, the nation survived all.

Meantime, the role the media is playing in seeking an enduring resolution to the Niger-Delta and Boko Haram impasse is worth commending. While discouraging the militancy of the enraged Niger-Delta youths on the one hand, and the sectarian (religious) advocates of Boko Haram on the other hand, the Nigerian media has always proposed and encouraged the use of dialogue between the government and the aggrieved parties as a sure means of resolving the crises. Equally, the long drawn controversy over the Bakassi Peninsula and the eventual amicable resolution of that conflict between Nigeria and Cameroon also attests to the power of the Nigerian media in positively influencing the direction of foreign policy engagements by the Nigerian government. Never at a time did the Nigerian media support the use of aggression in resolving the dispute but through careful reportage, the nation was guided through the legal tussle at the World court in Hague, the numerous sittings of the mixed boundary Commission and the subsequent peaceful boundary demarcations between the two countries (Alemoh, 2013, pp. 188-189).

\section{Conclusion}

This paper has examined the role of the Nigerian media in the quest for national development in Nigeria. The paper has shown that the Nigerian media has always been involved in the politics of the nation beginning from the colonial era. What this paper has succeeded in doing most is highlighting the contributions of the Nigerian media, as an institution, towards the advancement of the nation amidst sinister circumstances. The paper notes, however, that some of such contributions are not given prominence in media analysis in Nigeria. This calls for redirecting scholarly attention to the positive role the Nigerian media has played as a stakeholder in the nexus of factors which collectively have placed the country where she is today. Indeed, as the veteran journalist, Ray Ekpu (1990) opines, "journalism is an endeavour in service of the public good. Journalists must be just as dedicated to that good as they are to high professional standards". Abraham Ogbodo cited earlier in this article has noted that without the press playing its role as the fourth estate of the realm, there is no guarantee to safeguarding human rights. According to him:

...no governmental structure runs on the three arms without the fourth and still bears the inherent capacity to guarantee the inalienable rights of the individual. I can add that without a vigilant and virile Fourth Estate, totalitarian leaders will so readily consolidate the other three estates under the subterfuge of national interest or some plea of emergency to abbreviate the rights of citizens (my emphasis).

For such noble but risky patriotic fervor as demonstrated by the Nigerian media outlined in this discourse, the Nigerian media had to make sacrifices both in material and human losses. The military regimes that held the nation hostage for decades were fought and defeated with the full support of the Nigerian media. In this way, the Nigerian media has succeeded in winning a second independence for the nation, although, "from indigenous exploitative leaders" in the 
words of the renowned political scientist, Professor Claude Ake (of blessed memory). However, it would be hasty to conclude that the struggle with the indigenous exploitative leaders is over as the politicians even in the present dispensation are as good as the soldiers that were chased out of power earlier. The Nigerian press has not relented in its pursuit of overall development for the nation even with the restoration of democratic rule in the country. Recognizing this unique task, Prof. Dora Akunyili, (of blessed memory) former Minister of Information and Communications in Nigeria, in an address to the Nigerian Union of Journalists National Delegates Conference at Makurdi, Benue State, reported in the Pavillion Newspaper, May 1-19, 2009, p.8, charged the media to:

...help to explain government policies into digestible capsules for the people to comprehend. As journalists, I call upon you to write us out of poverty into prosperity, out of the decadence in our society into a land where our cultural values are enthroned, out of a corrupt society into an accountable and responsible one.

It is in the light of the foregoing analysis that we assert that the Nigerian media has not done badly in its role as the Fourth Estate of the Realm in the development of the Nigerian nation.

\section{References}

Adaja, T. A. (2016). Mass media in Nigeria and the quest for good governance and democratic sustainability In Wilson, D. (ed) Mass media and the electoral process in Nigeria, Uyo: ACCE.

Agbanu, V. (2008b). Ethical and Legal Issues in Public Relations Practice, In Agbanu and Nwabueze (eds) Readings in Mass Communication: Global Perspectives on Communication Issues, Owerri: Top Shelve Publishers.

Aina, A. D. (2003). Agenda-setting for political communication: A Nigerian experience, UNILAG Communication Review, 4(1)

Akinlade, A. A. (n.d). The influence of social media on the voting behaviour of the youth in south-east Nigeria. A dissertation submitted to the school of postgraduate studies, University of Nigeria, Nsukka assessed on 04/01/2019 from

http://repository.unn.edu.ng/bitstream/handle/123456789/4323/Akinlade\%2C\%20Ajibola\%20A..pdf?sequence=1\& isAllowed=y

Akunyili, D. (2009). An address to the Nigeria Union of Journalists National Delegates Conference at Makurdi, Pavillion Newspaper, May 1-19, p.8.

Alemoh, T. A. (2005). The influence of occupational socialization on the professional conduct of media practitioners: A study of journalists in Maiduguri. An M.A dissertation submitted to post-graduate school, University of Maiduguri.

Alemoh, T. A. (2013). Media as peace advocates: A reflection on Nigerian press coverage of the Bakassi Peninsula conflict (2002-2006), LWATI: A journal of contemporary research, 10(4), available @ https://www.ajol.info/index.php/lwati/issue/view/11079

Alemoh, T. A. (2017). Investigative journalism as a panacea to sustainable national development in Nigeria, In Wilson, D. (ed) Communication and economic development, Uyo: ACCE.

Anikwe, B. (2010). Guns against the Journalist, Vanguard, Wednesday, May 5, p.19

Asemah, E. (2011). Selected mass media themes, Jos: Jos University Press.

Chapter Two, S.22.Fundamental objectives and directive principles of state policy, 1999Constitution of the Federal Republic of Nigeria as amended.

CPJ Report (2015). Getting away with murder. CPJ's 2015 Global Impunity Index spotlights countries where journalists are slain and the killers go free. Available

Dominick, J. R. (2002). The dynamics of mass communication: media in the digital age ( $7^{\text {th }}$ edition), Boston: McGraw Hill.

Efiong, P. (2012). Nigeria and Biafra: my story, Uyo: Ibionolbom Welfare and Development Union (IWADU).

Ekpu, R. (1990). Nigeria's embattled fourth estate, In Journal of Democracy, 1(2), 106-116. https://doi.org/10.1353/jod.1990.0025

Folarin, B. A. (1998). Theories of mass communication: An introduction, Ibadan: Stirling-Hordens.

Golding, P. (1983). Media professionalism in the third world: the transfer of ideology, In Curran J., Gurevitch M., \& Woolacott J. (eds) Mass communication and society. London: Edwards Arnolds Publishers Ltd.

https://cpj.org/reports/2015/10/impunity-index-getting-away-with-murder.php\#moreassessed 19/11/2016. 
Madiebo, A. (1980). The Nigerian revolution and the Biafran War, Enugu: Fourth Dimension.

McBride, S. (1981). Many voices, one world, Paris: UNESCO.

Ogbodo, A. (2016).The media and democracy in Nigeria.The Guardian, 24 July.

Oguche, I., \& Tiamiyu, K. (2018). Classroom versus newsroom: who is right, who is wrong? InWilson, D. \& Batta, H. (eds) Communication education \& research in $21^{\text {st }}$ century Nigeria, Uyo: African Council for Communication Education (ACCE).

Okon, O. (1997). The Nigerian mass media: setting the agenda for national unity" In Daniel B. (ed) Mass communication: concepts and essays, Calabar:Wusen Press Limited.

Okpeh, O. O. (2005). Journalism and the challenges of ethnicity in Nigeria in the $21^{\text {st }}$ century, African Journal of Indigenous Development,2(1), December

Omu, F. (1978). Press and politics in Nigeria: 1880-1937, London: Longman GroupLtd.

Pate, U. (1997). Military rule and the Nigerian press: 1985-1993, Ph.D Thesis, Department of History, University of Maiduguri.

Pate, U. (2012). Practices and challenges of media performance in conflict prone multicultural Nigeria. In Mboho, M. \& Batta, H. (eds) The companion to communication and development issues: essays in honour of Prof. Des Wilson, Uyo: BSM Resources Limited.

Uche, L. (1989). Mass media people and politics in Nigeria, New Delhi: Concept Publishing

Uffot, E. (2009). Enugu now ready for media awards, Newswatch, November 16.

\section{Copyrights}

Copyright for this article is retained by the author(s), with first publication rights granted to the journal.

This is an open-access article distributed under the terms and conditions of the Creative Commons Attribution license which permits unrestricted use, distribution, and reproduction in any medium, provided the original work is properly cited. 